\title{
Magnetotelluric transect of Unzen graben, Japan: conductors associated with normal faults
}

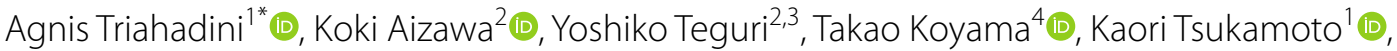 \\ Dan Muramatsu ${ }^{1}$ (D) Keita Chiba ${ }^{2}$ (D) and Makoto Uyeshima ${ }^{4}$ (D)
}

\begin{abstract}
We conducted a broadband magnetotelluric (MT) survey along a north-south transect across Unzen graben, Japan. The MT survey line is located $\sim 2 \mathrm{~km}$ west of the most recent lava dome and consisted of 27 stations along a 9-km profile. We estimated the 3-D resistivity structure and correlated it with the seismic reflection structure obtained by the same survey line as in the present study. The best-fit resistivity structure shows an upper resistive layer underlain by a moderately conductive layer. The resistive layer, which is interpreted as a cold groundwater zone, is cut by four faults marked by their relatively high conductivity. The underlying layer, which is interpreted as a hydrothermal-waterrich layer, also shows relatively conductive values near the faults. By assuming that the faults are imaged as relatively conductive zones, we infer the dip and depth extent of fracture zones around the faults. Beneath the Chijiwa Fault, which is the longest and most active fault of Unzen graben, the dominant conductor (C1) has a width of $2 \mathrm{~km}$ and extends down to below $4 \mathrm{~km}$ depth. C1 corresponds to a zone of strong seismic reflection and is located close to one of the pressure sources causing surface deformation. In this study, we interpret $\mathrm{Cl}$ as a network of fractures generated by the Chijiwa Fault to which magmatic volatiles are supplied from a deeper pressure source. Given that $\mathrm{Cl}$ extends to a greater depth and its resistivity is lower than other conductive zones, it is possible that earthquakes have occurred repeatedly on the Chijiwa Fault. In the center of the study area, we identify a vertically oriented body of high resistivity (R1) that corresponds to a zone of low seismic reflectivity. We interpret R1 as a cooled dyke complex that may have acted as a volcanic conduit.
\end{abstract}

Keywords: Magnetotellurics, Resistivity structure, Unzen volcano, Normal fault, Chijiwa Fault

\section{Introduction}

Unzen volcano, which is located on Shimabara Peninsula, Kyushu, Japan, is known for its remarkable 19911995 eruptions that repeatedly generated pyroclastic flows via the collapse of gravitationally unstable, growing lava domes. Before these eruptions, the volcano had been dormant for 198 years (Hoshizumi et al. 1999; Nakada et al. 1999). Seismic and geodetic measurements detected signs of unrest and associated movement of magma (Nishi et al. 1999; Umakoshi et al. 2001; Kohno et al. 2008). The hypocenters of tectonic earthquakes gradually shifted to shallower depths beneath Chijiwa

\footnotetext{
*Correspondence: agnis@sevo.kyushu-u.ac.jp

${ }^{1}$ Department of Earth and Planetary Sciences, Graduate School

of Science, Kyushu University, Fukuoka, Japan

Full list of author information is available at the end of the article
}

Bay to beneath the summit (Umakoshi et al. 2001) that was interpreted as magma migrating obliquely westward at an angle of $\sim 45^{\circ}$ to the horizontal plane from beneath Chijiwa Bay to the summit. Based on GPS and leveling measurements, Kohno et al. (2008) identified four pressure sources, located just beneath the inclined zone of earthquake hypocenters (sources A-D in Fig. 1).

This magmatic pathway was investigated by conducting a seismic survey. A north-south seismic reflection survey across Unzen graben revealed strong reflectors at a depth of $3 \mathrm{~km}$ below sea level, which corresponds to $1 \mathrm{~km}$ above pressure source B (Fig. 1a and Fig. 8a; Matsumoto et al. 2012). The reflectors are interpreted as the top of the magmatic chamber. However, this interpretation is based solely on reflector geometry. To better understand and estimate 


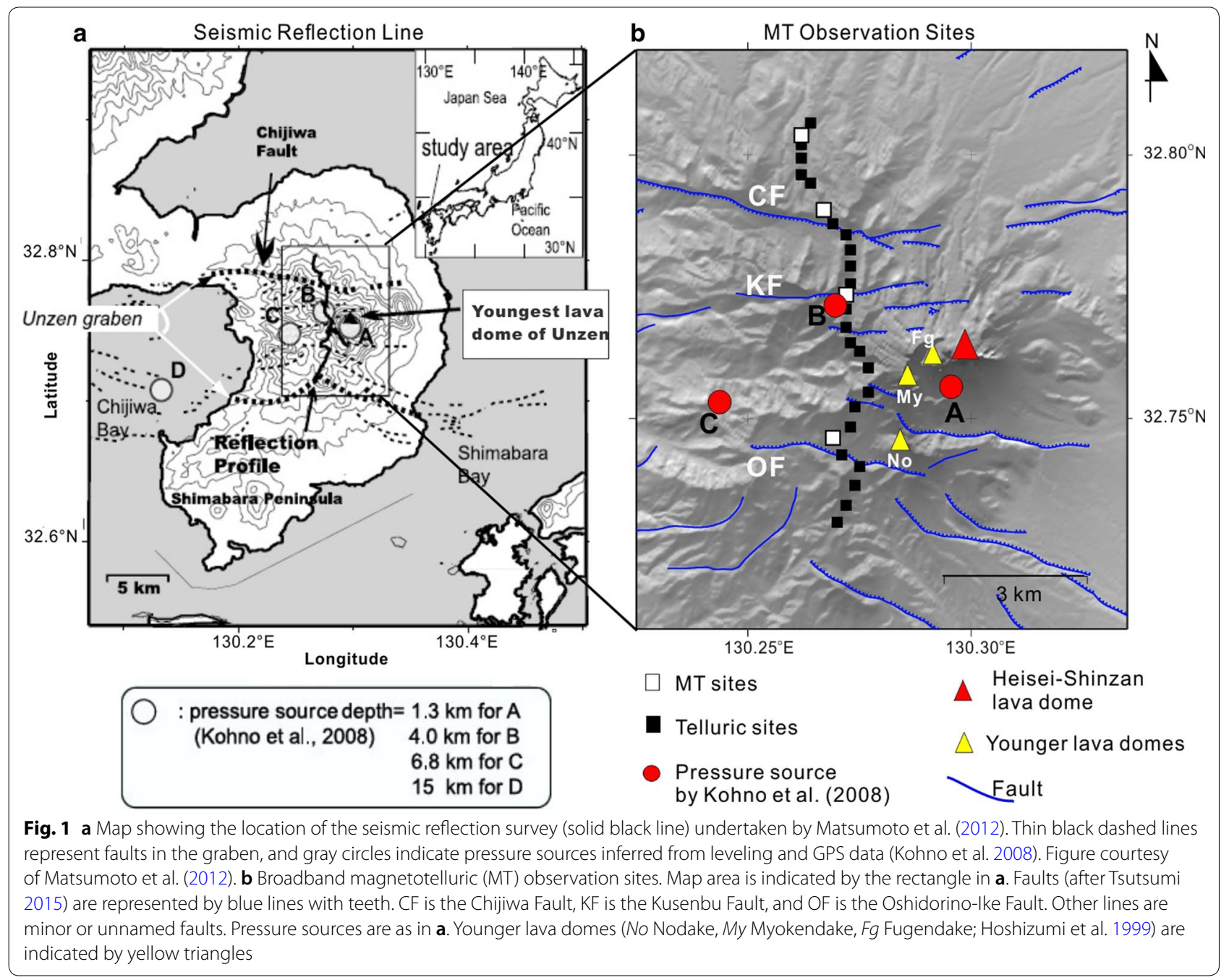

the physical properties of the subsurface structure, other types of geophysical analysis are required.

Electrical resistivity structure provides useful information on volcanoes, because it is highly sensitive to magma, hydrothermal fluids, and hydrothermally altered clay minerals (e.g., Nurhasan et al. 2006; Aizawa et al. 2009a, b; Bertrand et al. 2012; Hata et al. 2016; Seki et al. 2016). The resistivity structure of Unzen volcano has been previously estimated using magnetotelluric (MT) analysis and time-domain electromagnetic (TDEM) methods (Kagiyama et al. 1999; Komori et al. 2013; Srigutomo et al. 2008). Using 1-D analysis, Kagiyama et al. (1999) suggested the presence of shallow groundwater and deep magma and assessed magma-groundwater interaction during the 1990-1995 eruptions. Srigutomo et al. (2008) used 1-D analysis to suggest that volcanic gases are being supplied to a water-rich layer through a system of faults. Using 2-D modeling, Komori et al.
(2013) imaged a relatively resistive region beneath the younger lava domes and surrounding conductive zones. By comparing the model with scientific drilling data, they concluded that the conductive hydrothermal zone played an important role in heat and mass transfer within the Unzen magmatic system. These previous studies highlighted the importance of the shallow conductive hydrothermal zone in terms of volcanic activity. However, data from these surveys were processed using 1-D and 2-D inversions and were not sensitive to deeper structure beneath the hydrothermal zone. Furthermore, the site distribution in these studies was too sparse to investigate finer structures such as faults and conduits. To address these shortcomings, we performed a broadband MT survey along the same line as the seismic reflection survey by Matsumoto et al. (2012). Although the MT data were obtained along a single profile, we performed 3-D inversion and considered topography because of strong 3-D 
features in the MT data and steep topography. Then, we compared the resistivity profile with the seismic reflection profile of Matsumoto et al. (2012). Although MT and seismic reflections have been jointly interpreted in tectonically active or volcanic regions (e.g., Unsworth et al. 1997; Brasse et al. 2002; Comeau et al. 2016), correlating resistivity structure with a seismic reflection profile at fine spatial resolution is rare, especially at shallow levels beneath a volcano. We show how these two physical properties correlate with each other and discuss the relationships between magma, faults, and hydrothermal systems.

\section{Geological setting}

In Unzen graben, many east-west normal faults have developed under north-south tensile stress (Fig. 1). Our MT survey line intersects the Chijiwa Fault (CF), the Kusenbu Fault (KF), and the Oshidorino-Ike Fault (OF), as well as three minor unnamed faults (Matsuoka et al. 2005; Tsutsumi 1987, 2015). The CF, located near the northern boundary of the graben, is the longest $(19 \mathrm{~km}$ at the surface) and the most active fault in this region. The average displacement rate at the surface is estimated to range from $2.8 \mathrm{~m} / \mathrm{ka}$ in the east to $8.8 \mathrm{~m} / \mathrm{ka}$ in the west, with total surface displacement ranging from $38 \mathrm{~m}$ (east) to $180 \mathrm{~m}$ (west). Two other major faults (KF and OF) are located in the graben, with respective surface lengths of $5.0-8.5 \mathrm{~km}$ and average surface displacement rates of $0.5-4.0 \mathrm{~m} / \mathrm{ka}$, respectively (Matsuoka et al. 2005; Tsutsumi 1987). The graben is thought to extend to a depth of $1 \mathrm{~km}$ b.s.l. and is filled with volcanic products (Hoshizumi et al. 1999). The basement of the graben is mainly high-density rock, interpreted as Paleogene sediments. Approximately $2 \mathrm{~km}$ to the east of the profile, lava domes associated with the younger stages of the Unzen complex (Nodake and Myokendake) and currently active regions (Fugendake and Heisei Shinzan) are exposed (Fig. 1b). The line of the MT profile spans relatively old (300$150 \mathrm{ka})$ volcanic products.

\section{Broadband MT survey}

Magnetotellurics is a passive electromagnetic geophysical method that measures temporal variations in induced natural electromagnetic fields on the Earth's surface to derive the subsurface resistivity structure. We conducted an MT survey along an approximately 9-km-long northsouth profile (Fig. 1b, Additional file 1: Figure S1). Measurement sites were located along the same profile as the seismic reflection survey by Matsumoto et al. (2012). To image detailed structures, our stations were closely spaced at 300-400-m intervals. The survey consisted of 23 telluric sites recording only electric field variations and 4 MT sites recording both electric and magnetic field variations. At each MT site, a Metronix ADU07e logger was connected to three induction coils and five electrodes (one of which was used as a common ground) to measure the magnetic and electric fields, respectively. At telluric sites, electric fields $\left(E_{x}\right.$ and $\left.E_{y}\right)$ were recorded using ELOG1 K loggers (NT System Design). Observations were conducted between April 25 and May 8, 2018 . The typical recording duration at a given site was 7-10 days. The sampling frequencies were $32 \mathrm{~Hz}(00: 00-$ 23:50 UT) and $1024 \mathrm{~Hz}$ (17:00-18:00 UT).

\section{Data processing}

After data collection, the binary time series data were converted to text format time series data with physical units $(\mathrm{mV} / \mathrm{km}$ and $\mathrm{nT})$ using the frequency responses of induction coils and data loggers, and the dipole length of the electric field. Because the time series data were affected by cultural noise from a $60 \mathrm{~Hz}$ power line, we performed notch filtering to eliminate $60 \mathrm{~Hz}$ noise and its associated odd-order overtones (Aizawa et al. 2013). Next, we calculated the MT response function over a 0.003-3276.8-s period range using a bounded influence remote reference code (Chave and Thomson 2004). At sites where only telluric measurements were undertaken, we used the magnetic data of the nearest MT site (e.g., Munoz and Ritter 2013; Comeau et al. 2018; Tsukamoto et al. 2018). We confirmed that the use of different magnetic sites did not cause significant differences in the response functions. To obtain unbiased impedance, remote reference processing was performed by canceling incoherent noise between an observation site and a reference site (Gamble et al. 1979). As a reference magnetic site, we used data from the MT monitoring station at Iwo-Yama, located in the Kirishima Volcanic Complex (Aizawa et al. 2013). Although data quality over shorter periods was successfully improved, the data show significant scatter at periods greater than $10 \mathrm{~s}$. By visual inspection, we excluded outliers from the smoothed sounding curve. We also discarded a site located near a metal fence, as its impedance curves show unrealistic values. Phase tensor analysis (Caldwell et al. 2004) shows the variable orientations of the major axes of ellipses and large $|\beta|$ (Fig. 2), and the diagonal components of impedances dominate the off-diagonal components for longer periods (Additional file 2: Figure S2), all indicating 3-D structure in this region.

\section{2-D and 3-D inversions}

Before 3-D inversion, we conducted 2-D inversion using the code of Ogawa and Uchida (1996), employing only the $Z_{x y}$ impedances. The regional strike of the area has roughly E-W orientation according to geological evidence (i.e., graben and surface fault traces, such 


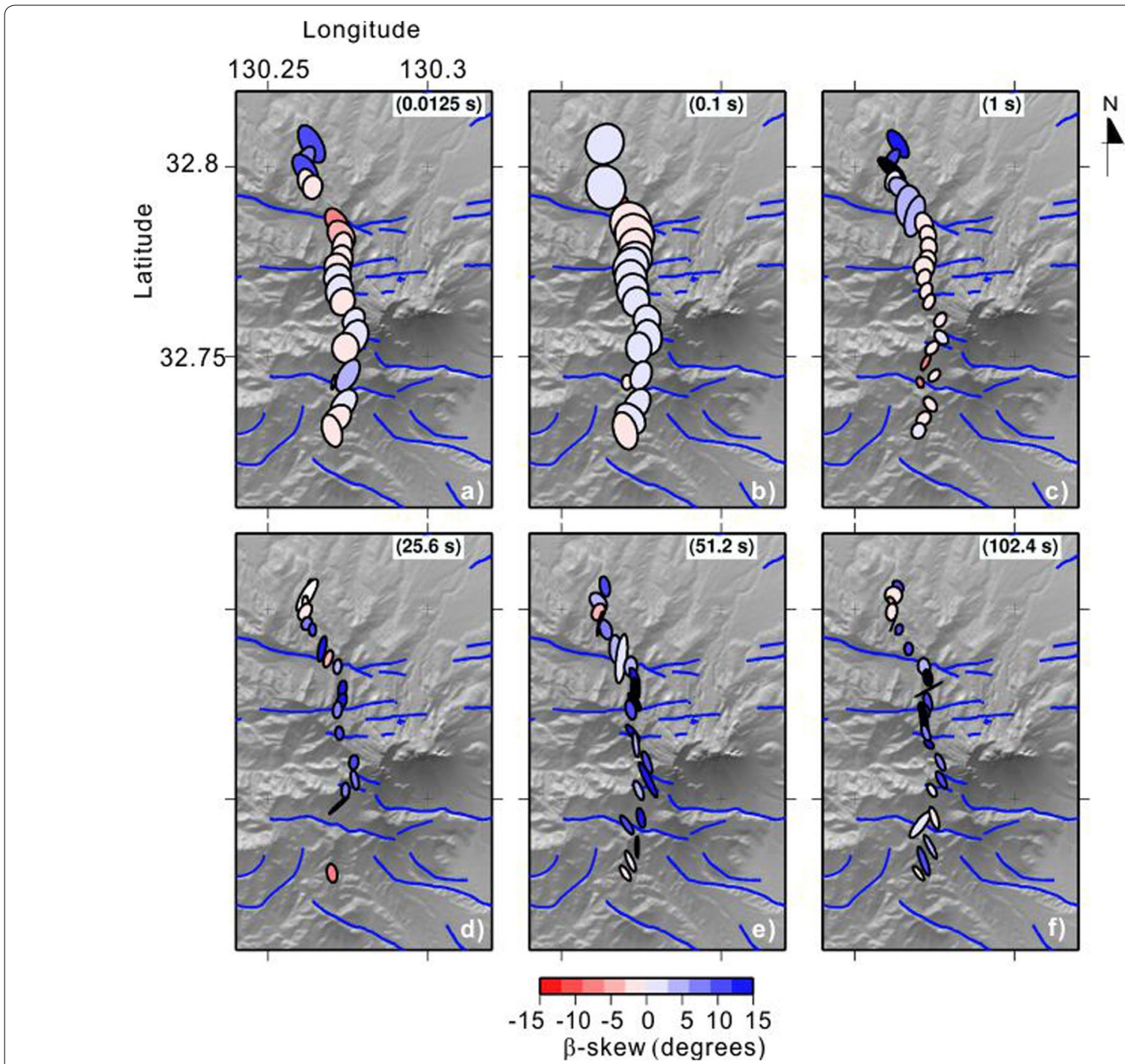

Fig. 2 Phase tensor ellipse (Caldwell et al. 2004) maps for different sounding periods (0.00125 s, 0.1 s, 1 s, 25.6 s, 51.2 s, 102.4 s). Color-filled ellipses represent the phase tensor ellipse with its orientation derived from azimuth $\alpha-\beta$. The color indicates $\beta$ skew angle. The sites having very large error bars (outliers) at the corresponding periods are removed. Site dependent of orientation strongly indicate 3-D behavior

as Chijiwa Fault) (i.e., Hoshizumi et al. 1999). On the assumption that the 2-D strike is the same as the surface traces of faults, $Z_{x y}$ corresponds to the transverse magnetic (TM) mode (electric current crosses the strike), while $Z_{y x}$ corresponds to the transverse electric (TE) mode (electric current flows along the strike). In this study, we used TM mode data, which is sensitive to lateral discontinuities of the structure and is relatively insensitive to the 3-D structure (e.g., Siripunvaraporn et al. 2005a).

We selected TM mode data of 20 periods (0.004$204.8 \mathrm{~s}$ ) and manually eliminated several outliers, particularly at periods $>12.8 \mathrm{~s}$. In the $2-\mathrm{D}$ inversion, we take into account that the $Z_{x y}$ at telluric sites are calculated using magnetic fields at different sites. The apparent resistivity of the initial model is $100 \Omega \mathrm{m}$ with an error floor of $10 \%$. Then, the final model was arrived at after 17 iterations. The RMS was 0.75 . Figure 5 a shows the best-fit 2-D structure.

In the case of strong 3-D features, 3-D inversion usually produces more reliable resistivity structures than 2-D inversion. The merits of applying 3-D inversion to single MT profile were first demonstrated by Siripunvaraporn et al. (2005a) using synthetic data. This procedure was consequently applied to real field data by Patro and Egbert (2011), Bertrand et al. (2013), Brasse et al. (2015), 
and Beka et al. (2016), and artifact structure produced in 2-D inversion can be eliminated in 3-D scheme. We performed 3-D inversion using the WSINV3DMT code, which is based on the data-space variant of Occam's 3-D inversion scheme (Siripunvaraporn et al. 2005a, b; Siripunvaraporn and Egbert 2009).

We inverted both the impedance tensor $\left(Z_{x x}, Z_{x y}, Z_{y x}\right.$, and $\left.Z_{y y}\right)$ and the geomagnetic transfer function $\left(T_{z x}\right.$ and $\left.T_{z y}\right)$. Initially, we picked data from a total of 16 periods between 0.004 and $3277 \mathrm{~s}$ at all stations. However, for several sites, considering data quality at the shortest and longest periods, we used the data from 0.0125 to $1638.4 \mathrm{~s}$. In the initial model, the horizontal mesh size was $150 \mathrm{~m}$ close to the profile, increasing logarithmically with increasing distance from the profile. Topographic effects can interrupt the MT transfer function, driven by charge accumulation on slopes, especially in the case of a mountainous survey region (e.g., Usui 2015; Käufl et al. 2018). To reduce this effect, we included topography in the inversion by adding $100-\mathrm{m}$ vertical mesh data from sea level to the highest point at $1700 \mathrm{~m}$ above sea level. The model consisted of 47 layers in the $z$ direction (including seven air layers), and 76 and 42 blocks in the $x$ and $y$ directions, respectively (Fig. 3). The half-space resistivity was initially set to $100 \Omega \mathrm{m}$, and the resistivity of air and sea was fixed at $10^{7} \Omega \mathrm{m}$ and $0.25 \Omega \mathrm{m}$, respectively. We tested a starting model with values of $1000 \Omega \mathrm{m}$ and $10 \Omega \mathrm{m}$; however, the RMS of each iteration always exceeded the $100 \Omega \mathrm{m}$ resistivity.
Errors in impedance and geomagnetic transfer functions were set to $10 \%$. Initially, 10 iterations were performed. After checking the RMS of each model, we re-inverted the data using the model with lowest RMS as the initial model for the second inversion. Previous MT 3-D studies (e.g., Patro and Egbert 2011; Comeau et al. 2016; Azeez et al. 2018) have also employed a similar approach to achieve better fitting result. As a result, RMS decreased significantly from 6.13 in the initial model of the first inversion to 1.60 in the final model of the second inversion. Figures 4 and 5 show horizontal and vertical slices of the final 3-D resistivity structure, respectively. Figure 6 shows the comparison of the observed data with the calculated data from the final resistivity structure.

The 2-D and 3-D models along the survey line are moderately similar (Fig. 5a, b). Both models show the first resistive layer is on top of the conductive layer, and the third layer displays high resistivity. However, significant differences are found at a depth of the third layer. Two conductive bodies in the 2-D model (black dashed lines in Fig. 5a) are not apparent in the 3-D model. The discrepancy between the models probably arose because of the 2-D modeling that was applied to a natural 3-D structure (Siripunvaraporn et al. 2005a; Brasse et al. 2015), especially for longer-period data. Thus, in this study, we focus on the 3-D structure.

The 3-D final resistivity structure essentially consists of three layers: a highly resistive layer (RL1) at the surface, a moderately conductive zone (CL1) beneath RL1 to a

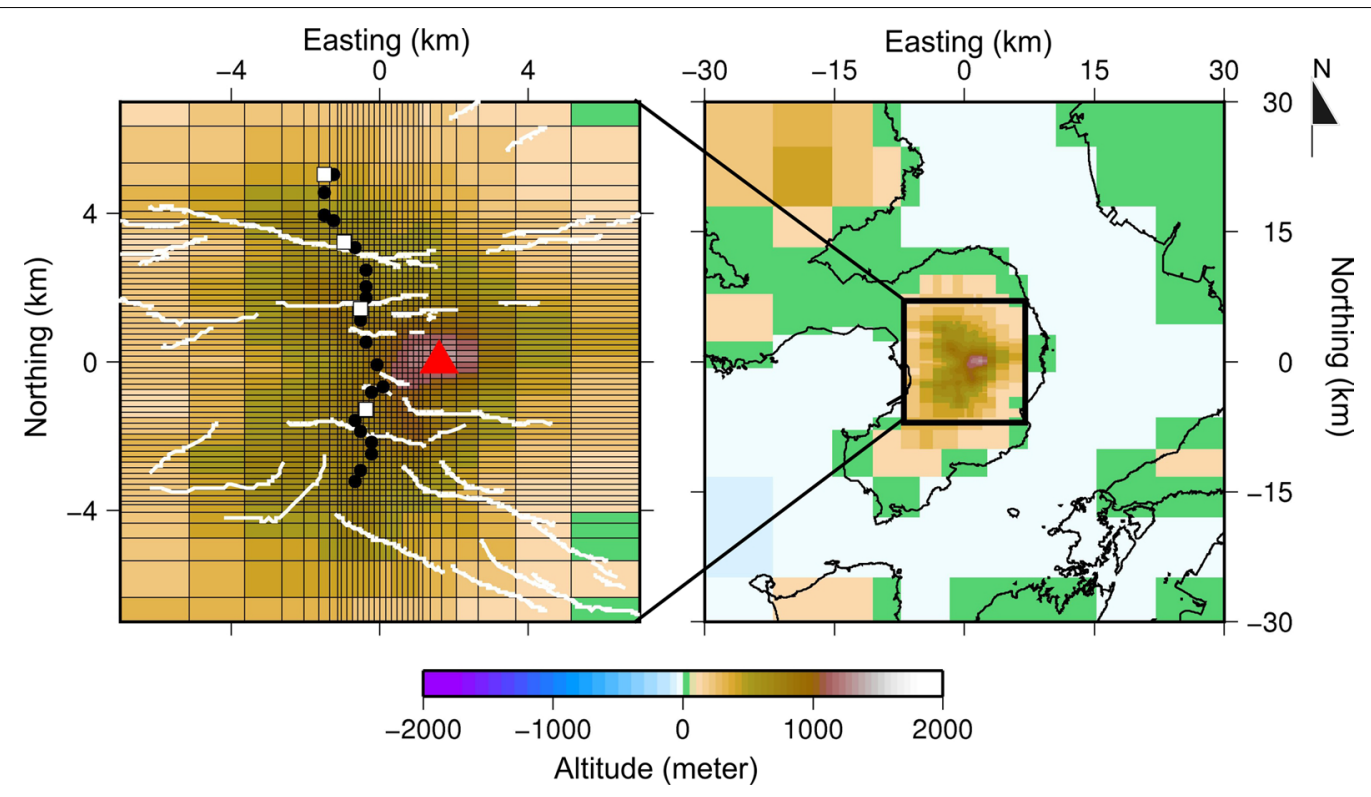

Fig. 3 Mesh configuration used in the inversion and its relative position to Shimabara Peninsula. a Mesh used in the inversion. The black circles and white squares indicate telluric sites and MT sites used in the inversion, respectively. Red triangle denotes Unzen's highest peak, the Heisei Shinzan lava dome. White lines indicate faults in the survey region. $\mathbf{b}$ The black square over Shimabara Peninsula indicates the area shown in $\mathbf{a}$ 

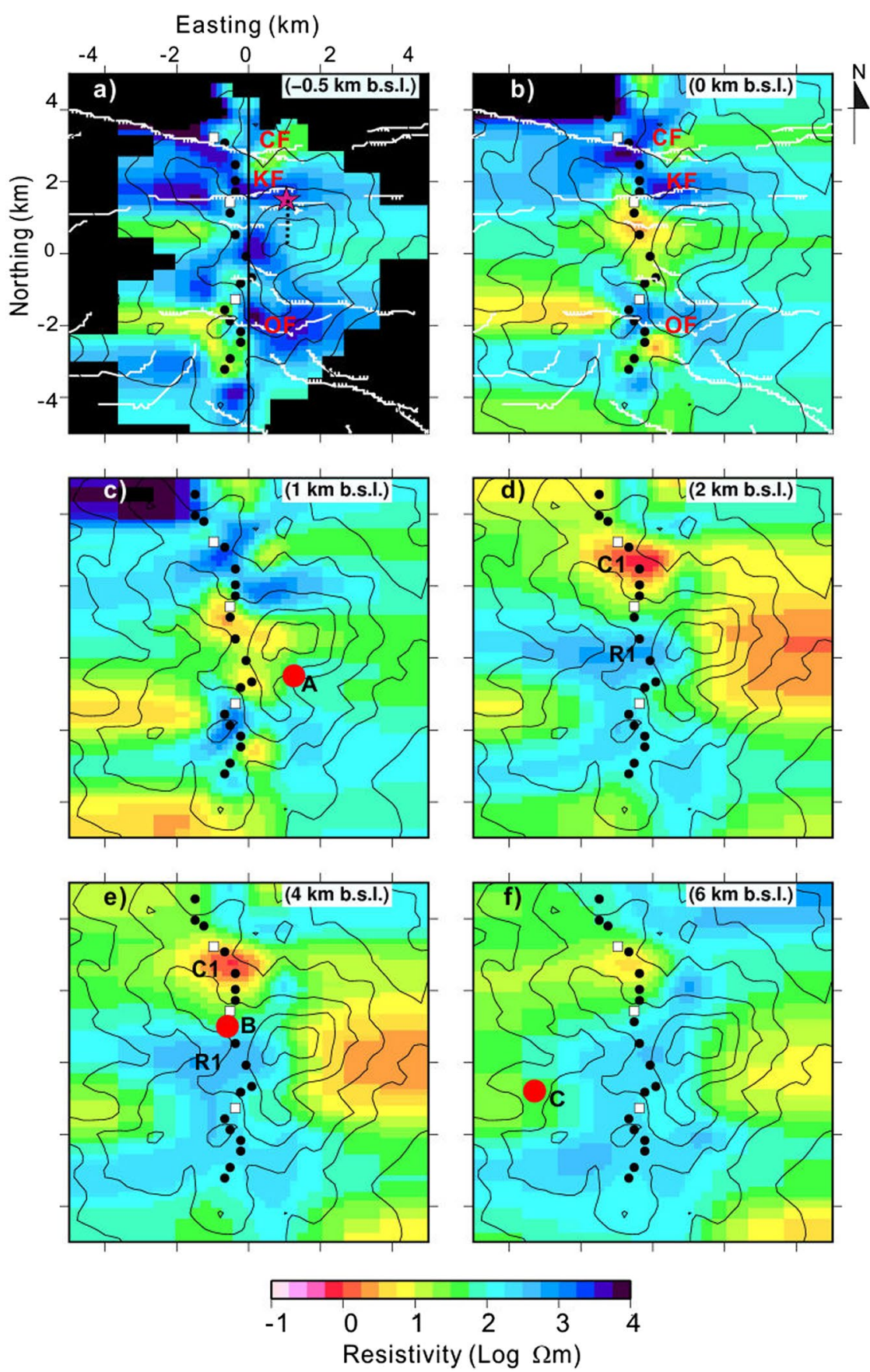

Fig. 4 Horizontal slices of the final 3-D resistivity structure at various depths below sea level (b.s.l). Topographic contour interval is $200 \mathrm{~m}$. Details are as in Fig. 2. The distinctive structures $\mathrm{C} 1$ and R1 are labeled. White lines show faults in the survey region (CF Chijiwa Fault, KF Kusenbu Fault, OF Oshidorino-Ike Fault), while red dots represent pressure sources identified by Kohno et al. (2008). The black line in the center of the top left panel marks the north-south cross section shown in Fig. 5b and 8b. The purple star and dashed black line indicate the USDP-4 drilling location and its subsurface trajectory. Note that the structure away from the profile is not constrained (for example, the sensitivity tests around pressure sources $\mathrm{A}$ and $($ show the small difference in RMS)

depth of $\sim 1 \mathrm{~km}$, and an underlying resistive zone. Within this structure, we noted two anomalies: a distinctive conductive body $(\mathrm{C} 1)$ in the northern part of the survey area, below sea level; and a vertically oriented resistive body (R1) in the center of transect. Before interpreting these structures, we conducted sensitivity tests to assess 


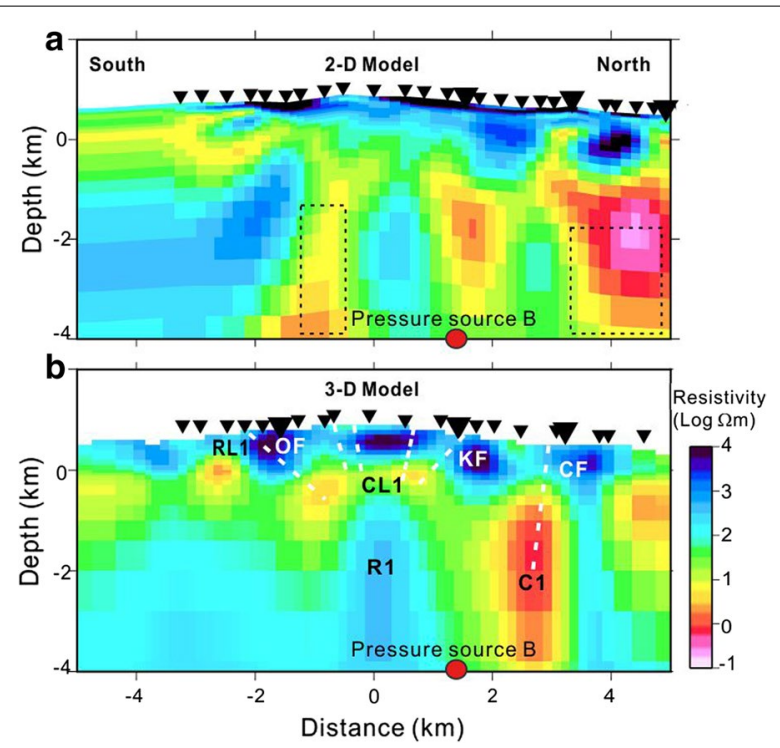

Fig. 5 Vertical slices of resistivity structure. a 2-D model. Inverted black triangles indicate observation sites used in the inversions. White dashed ellipses mark the low-resistivity zones that are not produced in the 3-D inversion. b 3-D model. RL1 (resistive layer 1), CL1 (conductive layer 1), R1, and C1 are the features discussed in Sects. 2-D and 3-D inversions and Discussion

the robustness of $\mathrm{C} 1$ and $\mathrm{R} 1$ within the model. Figure 7 shows the sounding curves of selected sites after sensitivity testing. After replacing $\mathrm{C} 1$ with a zone of $100 \Omega \mathrm{m}$ resistivity and performing a forward calculation, model RMS increased from 1.60 to 3.20. Replacing R1 with a $10 \Omega$ m resistivity zone resulted in an RMS increase from 1.60 to 1.70 . These RMS changes indicate that $\mathrm{C} 1$ is better constrained than R1. We did the replacement also in the southern extension of $\mathrm{C} 1$, the result of which is shown in Additional file 3: Figure S3. It raised the RMS to 1.67. The weaker constraint on R1 arose because the MT method is more sensitive to a conductive zone than a resistive zone. However, the small RMS increase observed in the sensitivity test of $\mathrm{R} 1$ suggests that this body is not a ghost structure.

\section{Discussion}

\section{Upper resistive layer (RL1)}

The upper resistive layer (RL1) extends from the surface to several hundred meters beneath sea level, corresponding to the estimated depth of high-density and highly magnetized formations that fill the graben (Inoue 2013; Okubo et al. 2006). The present survey line is largely covered by older Unzen lava and pyroclastic products from eruptions during the period 300-150 ka, which appear to be highly resistive (Matsumoto et al. 2012, after Hoshizumi et al. 2003). We interpret RL1 as a cold groundwater zone (meteoric water). Although the sampling points are limited in the area east of the Unzen volcano, the resistivity of cold groundwater at the mid-flank shows the resistivity of approximately $50-100 \Omega \mathrm{m}$ (Shimano 1999). The high resistivity of value RL1 is likely due to the water, considering the realistic porosity and Archie's law. In particular, the shallowest part is interpreted as an unsaturated groundwater zone, beneath which a cold aquifer occurs. A dominant feature of RL1 is that this high-resistivity zone (several $1000 \Omega \mathrm{m}$ ) is dissected by faults characterized by relatively conductive regions (several $100 \Omega \mathrm{m}$; Fig. 4b, 5b, 8b). Note that the faults might be inclined rather than vertical. Previous MT studies attributed the high conductivity of shallow fault-related zones to the presence of clay minerals, high fracture density, and well-developed fluid networks (e.g., Karas et al. 2017; Unsworth and Bedrosian 2004; Yamaguchi et al. 2010). It should be noted that because faults are usually characterized by thin planes, they are difficult to image using MT. The previous studies suggested that instead of imaging the actual fault planes, the MT technique images the relatively thick fractured or altered zones surrounding the faults. We suggest that relatively conductive zone around faults in RL1 represents a dense fracture network in which cold meteoric groundwater accumulates before flowing downward.

\section{Middle conductive layer (CL1)}

Beneath RL1, at $\sim 0-2 \mathrm{~km}$ beneath sea level, a conductive layer $(<50 \Omega \mathrm{m} C L 1)$ is identified. We interpret CL1 as a hot, groundwater-rich layer characterized by hydrothermal alteration, as also indicated by previous studies. Density and magnetization distributions show that CL1 is correlated with hydrothermally altered Neogene rock characterized by low magnetization $(1 \mathrm{~A} / \mathrm{m})$ and high density (Inoue 2013; Okubo et al. 2006).

CL1 contains a relatively low-resistivity zone; in particular, beneath the $C F$, a zone of low resistivity $(<10 \Omega \mathrm{m})$ extends to greater depth. This conductor is separately referred to as $\mathrm{C} 1$ and discussed below. Conductive zones underlying faults have been reported previously and are interpreted as fractured regions that are rich in crustal fluids (Becken and Ritter 2012; Karas et al. 2017; Kaya et al. 2013; Xiao et al. 2017; Azeez et al. 2018). Considering the relatively conductive zone found beneath the faults at the same depth as RL1, as well as identification of fault planes in the seismic reflection profile (Fig. 8b), we interpret this region as a deeper extension of the fracture zone, given that fault zones are relatively conductive. In Figs. $5 \mathrm{~b}$ and $8 \mathrm{~b}$, the white dashed line indicates the fractured zones associated with the fault inferred from the location of relatively conductive zones at the depth of RL1 and CL1. 


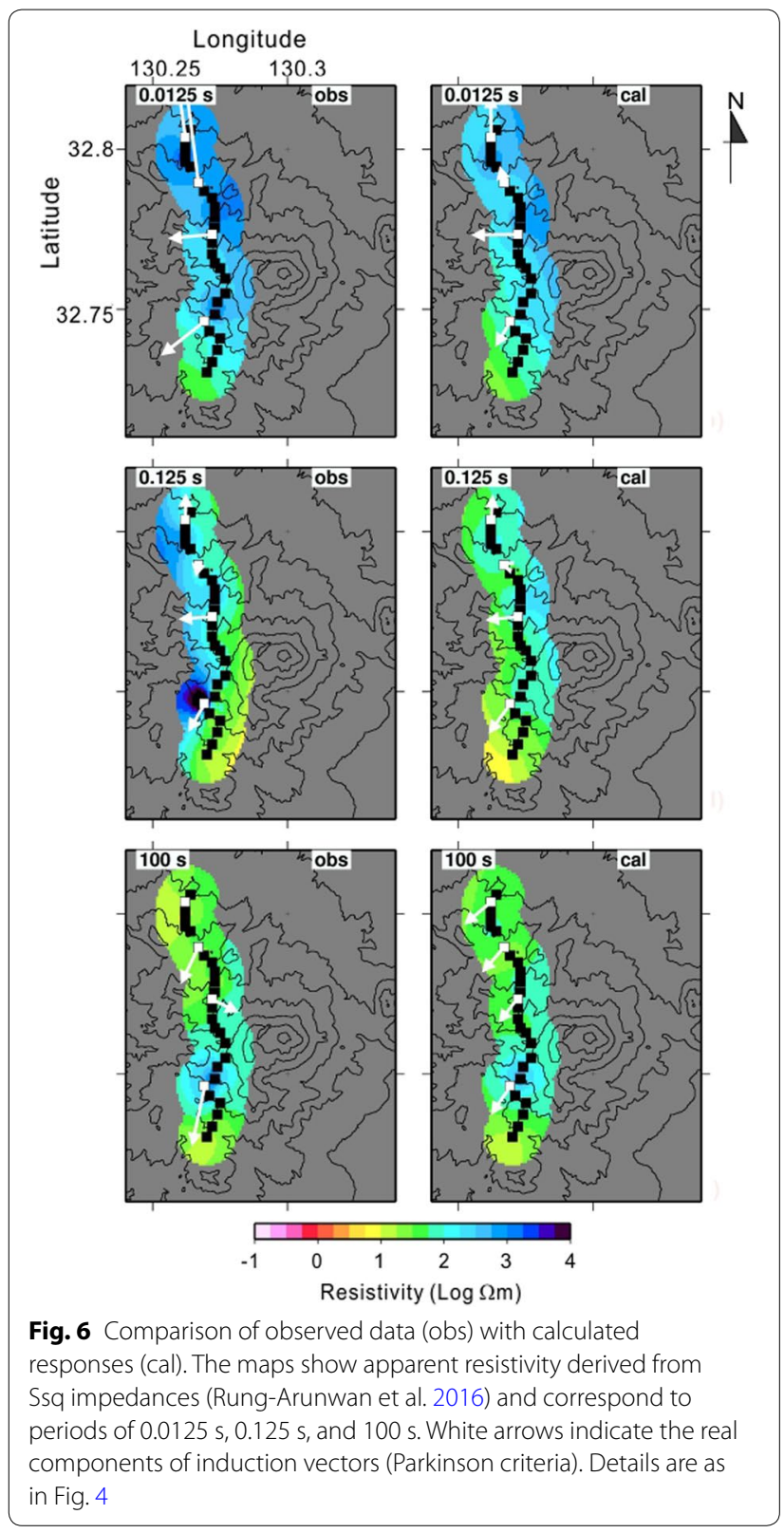

\section{Broad, highly conductive body (C1)}

$\mathrm{C} 1$ is the dominant feature of the resistivity structure. The upper part of $\mathrm{C} 1$, approximately at the depth 500 $700 \mathrm{~m}$ below sea level, corresponds to CL1. Although we could not examine the off-profile extension of $\mathrm{C} 1$, it is located near the CF (Chijiwa Fault) and pressure source B by Kohno et al. (2008). Some MT studies have suggested that a dominant conductive body can be interpreted as a magmatic body (e.g., Diaz et al. 2015; Hill et al. 2015; Hata et al. 2016; Brasse et al. 2015; Comeau et al. 2016; Cordell et al. 2018), but C1 is too large and shallow to represent a magma reservoir. $\mathrm{C} 1$ occupies a volume of $\sim 10 \mathrm{~km}^{3}$, compared with $0.2 \mathrm{~km}^{3}$ of magma erupted during the period 1991-1995 (Nakada and Motomura 1999). The lack of geothermal activity above $\mathrm{C} 1$ is also inconsistent with the interpretation of $\mathrm{C} 1$ as a magma reservoir. According to Kohno et al. (2008), pressure source B is located $\sim 4 \mathrm{~km}$ beneath sea level. If C1 represents a volume of interconnected melt, the pressure source would be observed at the top of $\mathrm{C} 1$, as a result of its buoyancy, rather than far beneath the top of $\mathrm{C} 1$. In this study, we interpret $\mathrm{C} 1$ as an interconnected fracture network around the CF, to which volatiles are supplied from pressure source $B$.

It is commonly thought that faults act as pathways for volatiles (e.g., Becken et al. 2011; Becken and Ritter 2012; Ichihara et al. 2011; Aizawa et al. 2016). The eruptions of Unzen volcano during 1991-1995 were effusive (i.e., mild) and were considered to have resulted from effective degassing during magma ascent. The degassing might have been maintained by volcanic gas discharge along many E-W trending faults (e.g., Komori et al. 2014), especially along the Chijiwa Fault, which is the longest and most active fault in Unzen graben. Indeed, groundwater gas analysis around Unzen volcano suggests that the CF provides a surface escape route for magmatic $\mathrm{CO}_{2}$ (Ohsawa et al. 2002).

C1 extends to a greater depth than the conductive zones beneath other faults, and the resistivity of $\mathrm{C} 1$ is lower than that of the zones beneath other faults. Given that $\mathrm{C} 1$ is interpreted to have originated by fracturing related to fault activity, it is possible that earthquakes have occurred repeatedly on the Chijiwa Fault.

\section{Vertical resistive body (R1)}

A comparison of the seismic reflection profile and the resistivity structure reveals a correlation between the sub-vertical high-resistivity zone (R1) and a narrow vertical zone of low reflectivity in the center of the survey line (Fig. 8). We interpret R1 as a cooled conduit through which dykes intruded to approach the summit. This interpretation is consistent with that of Matsumoto et al. (2012). The scientific drilling at site USDP4 (1.5 km east of the MT profile) revealed relatively high resistivity $(\sim 100 \Omega \mathrm{m})$, low porosity $(<0.25)$, and high density $(2.5 \mathrm{~g} /$ $\left.\mathrm{cm}^{3}\right)$ within the conduit due to the presence of solidified dykes related to eruptions of various ages (Ikeda et al. 2008; Sakuma et al. 2008). The presence of consolidated magma, low porosity, and/or high-density rocks are all plausible explanations of the high resistivity. Many MT studies have made similar interpretations of high-resistivity zones (e.g., Aizawa et al. 2008, 2009b, 2014 Diaz et al. 2015 Bedrosian et al. 2018). The result of the scientific drilling supports our interpretation of R1. 


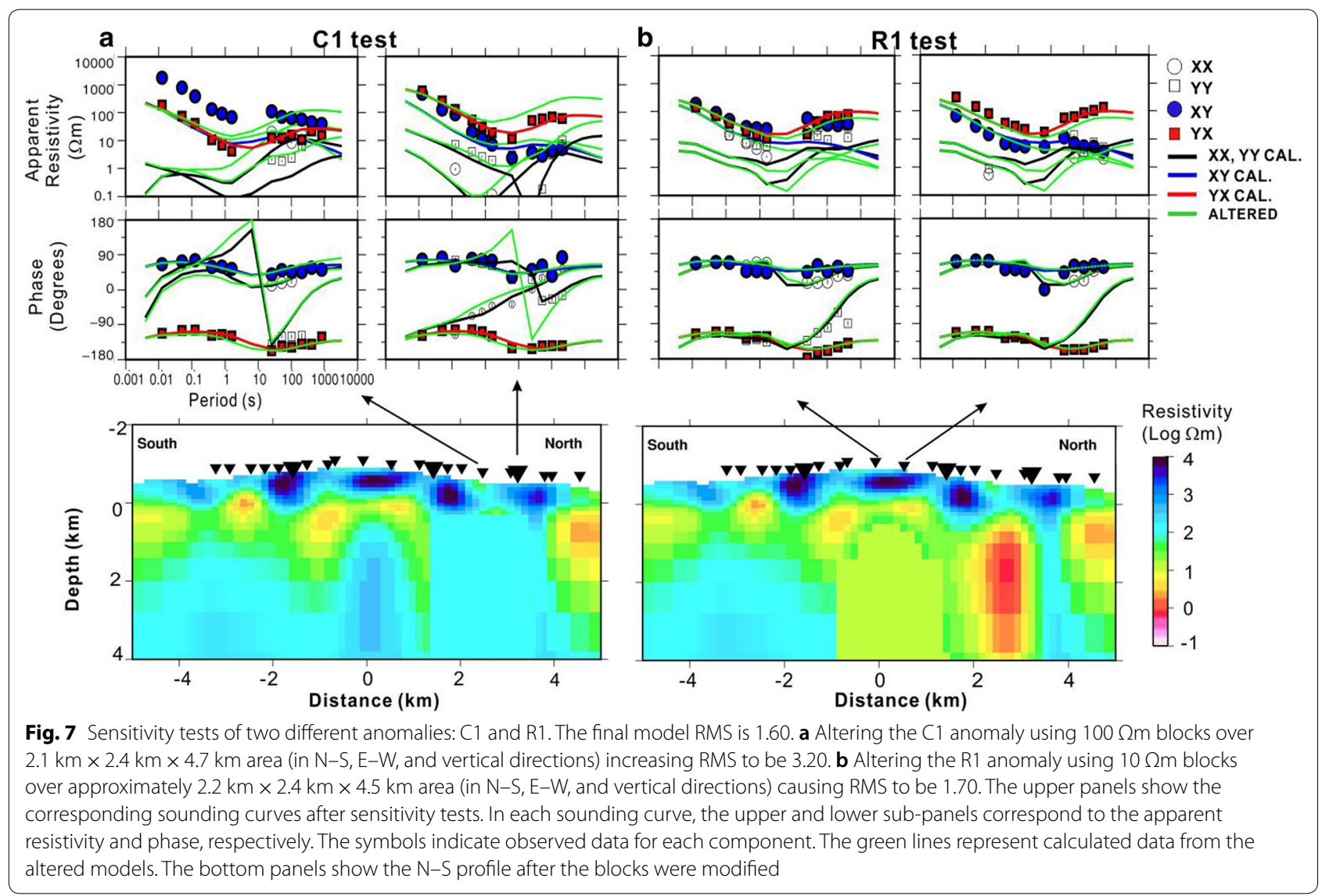

Although it is not confirmed that R1 is related to the latest (1990-1995) eruptions, the 500-m horizontal width of dykes confirmed by the drilling study is consistent with the horizontal extent of R1. The drilled conduit consists of multiple dykes and veins from various eruption stages, and the widths of individual dikes are up to $40 \mathrm{~m}$. The dikes in the deepest part of the drill hole $(\sim 100 \mathrm{~m}$ below sea level) are believed to represent the most recent conduit, as inferred from petrological analysis, and these rocks cooled to $<200{ }^{\circ} \mathrm{C}$ within nine years after the eruptions (Nakada et al. 2005; Ikeda et al. 2008). Hydrothermal fluid circulation was determined to be the most likely cause of cooling (Fujimitsu et al. 2008). The moderately conductive layer CL1 and highly conductive body C1 in this study, interpreted as hydrothermal-water-rich layers, may be responsible for cooling the conduit (R1).

\section{Relationship between resistivity and seismic reflection}

A comparison of the resistivity structure with the seismic reflection profile of Matsumoto et al. (2012) revealed that RL1, CL1, and C1 correlate with areas of strong seismic reflectivity (Fig. 8). On the other hand, the resistive zone beneath CL1 is imaged as zones of weak reflectivity. On the basis of these spatial correlations and the interpretations in Sects. Upper resistive layer (RL1)-Vertical resistive body (R1), we suggest that an interconnected pore network controls the relationship between electric resistivity and seismic reflectivity. Several qualitative interpretations have been made. Joint interpretation of MT and seismic data suggests that fluid-rich zones are indicative of high porosity with good connectivity and are electrically conductive (Hyndman and Shearer 1989; Jones 1987; Unsworth et al. 1997; Yan et al. 2016). Differences in porosity may create large contrasts in elastic properties, thus enhancing reflectivity in areas of high porosity. The multilayered structures characteristics of volcanic deposits may also contribute to high seismic reflectivity since it has high porosity, such as found in RL1. CL1 and C1 are also interpreted as hydrothermalwater-rich zones marked by high porosity and maintained interconnectivity. Consequently, both of these areas show strong reflectivity. In contrast, the resistive zone beneath CL1, which might correspond to the basement of Unzen volcano, is interpreted as a zone of low porosity and consequently shows weak reflectivity. Similar relationships between resistivity data and seismic profiles, and comparable interpretations, have been 


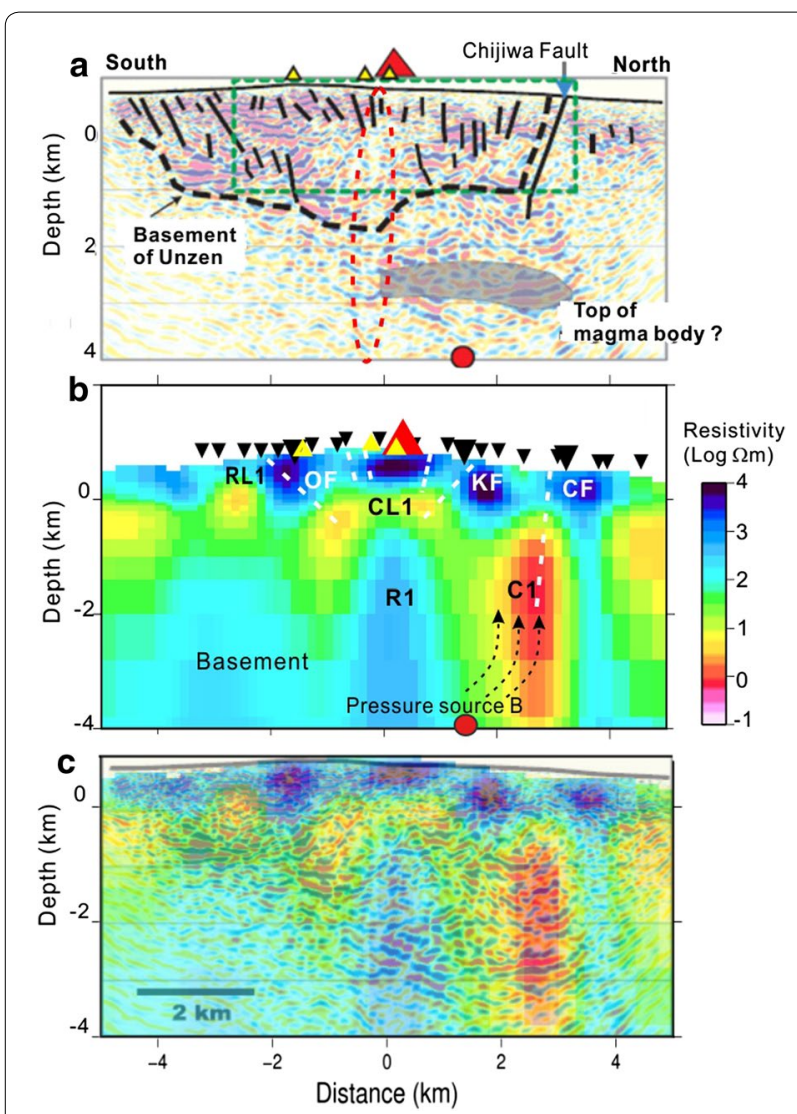

Fig. 8 a Cross section of the seismic reflection survey and interpretation (modified from Matsumoto et al. 2012). Red dashed ellipse in the center of the profile marks a possible conduit. $\mathbf{b} \mathrm{N}-\mathrm{S}$ vertical slice of the 3-D resistivity structure. (Location is shown in Fig. 4.) $\mathbf{c}$ The figures $\mathbf{a}, \mathbf{b}$ are overlaid. Inverted triangles show MT measurement sites (large triangles: MT sites; small triangles: telluric sites). White dashed lines indicate the inferred deep extension of faults (CF Chijiwa Fault, KF Kusenbu Fault, OF Oshidorino-Ike Fault; shorter lines are minor or unnamed faults). Pressure source $B$ is indicated by a red solid circle. Black dashed arrows represent the inferred movement of released volatiles. See text for details

reported for paleo-magmatism in Sweden (Hubert et al. 2013; Yan et al. 2016).

The estimated dip, depth extent, and the number of faults detected in this study differ slightly from those estimated by Matsumoto et al. (2012). For example, the $\mathrm{KF}$ is imaged as sub-vertical in the seismic reflection profile, whereas the MT model suggests it dips toward the south. Seismic profiles show offsets in reflection patterns, allowing fault planes to be identified by their displacement (e.g., Matsumoto et al. 2012). In contrast, MT cannot image fault planes but can identify voluminous fracture zones (e.g., Unsworth and Bedrosian 2004; Yamaguchi et al. 2010; Karas et al. 2017). It is possible that fault planes and their associated fractured zones have different dip angles.

\section{Conclusion}

The resistivity structure beneath our survey line basically shows three-layer structure. The first layer is nearsurface high-resistivity zone that corresponds to a zone of cold groundwater with old Unzen deposits. This layer is cut by four faults. The second layer is the mid-conductive layer associated with hydrothermal zone which shows relatively conductive values near the faults. The third layer is a bottom resistive zone related to the basement of the Unzen graben. At the same depth as the third layer, we found two distinctive anomalies. One is a highly conductive zone (C1) beneath Chijiwa Fault. Another is highly resistive zone R1 in the center of profile. $\mathrm{C} 1$ is interpreted as zone of interconnected fracture network around Chijiwa Fault, to which volcanic fluids are supplied from deeper pressure source (B). Given that $\mathrm{C} 1$ extends to a greater depth than the conductive zones beneath other faults, and its resistivity is lower than that of other zones, it is possible that earthquakes have occurred repeatedly on the Chijiwa Fault. R1 is interpreted as the cooled conduit of Unzen volcanism and consists of lava dykes and veins related to eruptions of various ages. Based on the correlation between the resistivity and seismic reflection structures, we conclude that the interconnected pore network controls the relationship between resistivity and reflections.

\section{Additional files}

Additional file 1. Figure S1. MT station and corresponding names. The subsequent sounding curves are shown in Additional file 2: Figure S2. MT station and Telluric station are denoted as white rectangle and black rectangle respectively. The 'SITE $X$ ' is the site being excluded in the inversion. The red triangle shows Heisei Shinzan lava dome.

Additional file 2. Figure $\mathbf{S}$. Sounding curve of apparent resistivity (upper part, in $\Omega \mathrm{m}$ ) and phase (lower part, in degree) to the corresponding periods (in second) from all stations used in the 3-D inversion. (a) Sites numbered 1 to 12 and (b) sites numbered 13 to 25 . The location of each station is explained in Additional file 1: Figure S1. Symbols and lines are detailed in the legend.

Additional file 3. Figure $\mathbf{S 3}$. Sensitivity test of the southern extension of $\mathrm{C} 1$ anomaly by changing the resistivity of the area with $100 \Omega \mathrm{m}$ blocks. The altered zone extends to $2.4 \mathrm{~km}$ in E-W direction and $4.7 \mathrm{~km}$ in vertical direction. The RMS of modified model is 1.67 from initially 1.60 . Small increase in the RMS indicates that the width of $\mathrm{C} 1$ is less constrained. The upper and bottom panel as well as symbols and legends are same as Fig. 7. 


\section{Authors' contributions}

AT, KA, and YT designed the field survey. AT carried out the analysis and drafted the manuscript. All authors contributed to MT data acquisition and discussion. All authors read and approved the final manuscript.

\section{Author details}

${ }^{1}$ Department of Earth and Planetary Sciences, Graduate School of Science, Kyushu University, Fukuoka, Japan. ${ }^{2}$ Institute of Seismology and Volcanology, Faculty of Science, Kyushu University, 744 Motooka, Nishi-ku, Fukuoka 819-0395, Japan. ${ }^{3}$ Japan Meteorological Agency, 4-1 Korimoto, Kagoshima 890-0068, Japan. ${ }^{4}$ Earthquake Research Institute, University of Tokyo, Yayoi 1-1-1, Bunkyo-ku, Tokyo 113-0032, Japan.

\begin{abstract}
Acknowledgements
We thank forestry officers for granting access to conduct field campaigns. We appreciate $\mathrm{S}$. Matsumoto and $\mathrm{H}$. Shimizu for extensive discussions and suggestions while interpreting the results. We appreciate H. Tsutsumi, M. Ueda, and Geospatial Information Authority of Japan for supplying the fault data. SEVO students Y. Hayashida, K. Takeishi, Y. Yuasa, S. Watanabe, and Y. Odasaki are thanked for their help with the MT survey. Our gratitude goes to Y. Ogawa for supplying 2-D inversion code and W. Siripunvaraporn for supplying his 3-D inversion code. We used the computer systems of the Earthquake and Volcano Information Center of the Earthquake Research Institute, the University of Tokyo. Comments from two anonymous reviewers were helpful in improving the manuscript. This study was supported by the Ministry of Education, Culture, Sports, Science and Technology (MEXT) of Japan, under its Earthquake and Volcano Hazards Observation and Research Program, and funded by JSPS KAKENHI (JP15K17751). AT sincerely thanks the LPDP Scholarship (Indonesian Education Scholarship) for funding her education at Kyushu University.
\end{abstract}

\section{Competing interests}

The authors declare that they have no competing interests.

\section{Availability of data and materials}

The datasets are available from the corresponding author AT on reasonable request.

\section{Consent for publication}

Not applicable.

\section{Ethics approval and consent to participate}

Not applicable.

\section{Funding}

This study was supported by the Ministry of Education, Culture, Sports, Science and Technology (MEXT) of Japan, under its Earthquake and Volcano Hazards Observation and Research Program and KAKENHI (Grant No. 15K17751). AT sincerely thanks the LPDP Scholarship (Indonesian Education Scholarship) for funding her education at Kyushu University.

\section{Publisher's Note}

Springer Nature remains neutral with regard to jurisdictional claims in published maps and institutional affiliations.

\section{Received: 13 October 2018 Accepted: 18 February 2019}

Published online: 04 March 2019

\section{References}

Aizawa K, Ogawa Y, Hashimoto T, Koyama T, Kanda W, Yamaya Y, Mishina M, Kagiyama T (2008) Shallow resistivity structure of Asama Volcano and its implications for magma ascent process in the 2004 eruption. J Volcanol Geotherm Res 173(3-4):165-177. https://doi.org/10.1016/j.jvolgeores .2008.01.016

Aizawa K, Ogawa Y, Ishido T (2009a) Groundwater flow and hydrothermal systems within volcanic edifices: delineation by electric selfpotential and magnetotellurics. J Geophys Res Solid Earth. https://doi. org/10.1029/2008jb005910
Aizawa K, Ogawa Y, Mishina M, Takahashi K, Nagaoka S, Takagi N, Sakanaka S, Miura T (2009b) Structural controls on the 1998 volcanic unrest at Iwate volcano: relationship between a shallow, electrically resistive body and the possible ascent route of magmatic fluid. J Volcanol Geotherm Res 187(1-2):131-139. https://doi.org/10.1016/j.jvolgeores.2009.08.009

Aizawa K, Koyama T, Uyeshima M, Hase H, Hashimoto T, Kanda W, Yoshimura R, Utsugi M, Ogawa Y, Yamazaki K (2013) Magnetotelluric and temperature monitoring after the 2011 sub-Plinian eruptions of Shinmoe-dake volcano. Earth Planets Space 65:539-550. https://doi.org/10.5047/ eps.2013.05.008

Aizawa K, Koyama T, Hase H, Uyeshima M, Knada W, Utsugi M, Yoshimura R, Yamaya Y, Hashimoto T, Yamazaki K, Komatsu S, Watanabe A, Miyakawa K, Ogawa Y (2014) Three-dimensional resistivity structure and magma plumbing system of the Kirishima Volcanoes as inferred from broadband magnetotelluric data. J Geophys Res Solid Earth 119:198-215. https://doi. org/10.1002/2013/2013jb010682

Aizawa K, Sumini H, Uyeshima M, Yamaya Y, Hase H, Takahashi HA, Takahashi M, Kazahaya K, Ohno M, Rung-Arunwan T, Ogawa Y (2016) Gas pathways and remotely triggered earthquakes beneath Mt. Fuji, Japan. Geology 44:127-130. https://doi.org/10.1130/g37313.1

Azeez KKA, Mohanb K, Veeraswamya K, Rastogib BK, Guptaa AK, Harinarayanaa $T$ (2018) 3D crustal resistivity structure beneath the Wagad aftershock zone of the 2001 Bhuj earthquake, Kutch, India: heterogeneous resistivity structure controlled by widespread fluid infiltration and clues to aftershocks pattern. Tectonophysics 747-748:54-67. https://doi.org/10.1016/j. tecto.2018.09.014

Becken M, Ritter O (2012) Magnetotelluric studies at the San Andreas fault zone: implications for the role of fluids. Surv Geophys 33(1):65-105. https //doi.org/10.1007/s10712-011-9144-0

Becken M, Ritter O, Bedrosian PA, Weckmann U (2011) Correlation between deep fluids, tremor and creep along the central San Andreas fault. Nature 480(7375):87-U248. https://doi.org/10.1038/nature10609

Bedrosian PA, Peacock JR, Bowles-Martinez Schultz A, Hill GJ (2018) Crustal inheritance and top-down control on arc magmatism at Mount St Helens. Nat Geosci 11:865-870. https://doi.org/10.1038/s4156 1-018-0217-2

Beka TI, Smirnov M, Birkelund Y, Senger K, Bergh SG (2016) Analysis and 3D inversion of magnetotelluric crooked profile data from central Svalbard for geothermal application. Tectonophys 686:98-115. https://doi. org/10.1016/j.tecto.2016.07.024

Bertrand EA et al (2012) Magnetotelluric imaging of upper-crustal convection plumes beneath the Taupo Volcanic Zone, New Zealand. Geophys Res Lett 39:L02304. https://doi.org/10.1029/2011 gl050177

Bertrand EA, Caldwell TG, Hill GJ, Bennie SL, Soengkono S (2013) Magnetotelluric imaging of the Ohaaki geothermal system New Zealand: implications for locating basement permeability. J Volcanol Geotherm Res 268:36-45

Brasse H, Lezaeta P, Rath V, Schwalenberg K, Soyer W, Haak V (2002) The Bolivian Altiplano conductivity anomaly. J Geophys Res 107:2096. https://doi. org/10.1029/2001JB000391

Brasse H, Schäfer A, Díaz D, Alvarado GE, Muñoz A, Mütschard L (2015) Deepcrustal magma reservoirs beneath the Nicaraguan volcanic arc, revealed by 2-D and semi 3-D inversion of magnetotelluric data. Phys Earth Planet Inter 248:55-62. https://doi.org/10.1016/j.pepi.2015.08.004

Caldwell TG, Bibby HM, Brown C (2004) The magnetotelluric phase tensor. Geophys J Int. https://doi.org/10.1111/j.1365-246x.2004.02281.x

Chave AD, Thomson DJ (2004) Bounded influence magnetotelluric response function estimation. Geophys J Int 157(3):988-1006. https://doi. org/10.1111/j.1365-246X.2004.02203.x

Comeau MJ, Unsworth MJ, Cordell D (2016) New constraints on the magma distribution and composition beneath Volcan Uturuncu and the southern Bolivian Altiplano from magnetotelluric data. Geosphere. https://doi. org/10.1130/ges01277.1

Comeau MJ, Kaufl JS, Becken M, Kuvshinov A, Grayver AV, Kamm J, Demberel S, Sukhbaatar U, Batmagnai E (2018) Evidence for fluid and melt generation in response to an asthenospheric upwelling beneath the Hangai Dome, Mongolia. Earth Planet Sci Lett 487:201-209. https://doi.org/10.1016/j. epsl.2018.02.007

Cordell D, Unsworth MJ, Diaz D (2018) Imaging the Laguna del Maule Volcanic Field, central Chile using magnetotellurics: evidence for crustal melt regions laterally-offset from surface vents and lava flows. Earth Planet Sci Lett 488:168-180. https://doi.org/10.1016/j.epsl.2018.01.007 
Diaz D, Heise W, Zamudio F (2015) Three-dimensional resistivity image of the magmatic system beneath Lastarria volcano and evidence for magmatic intrusion in the back arc (northern Chile). Geophys Res Lett 42(13):52125218. https://doi.org/10.1002/2015gl064426

Fujimitsu Y, Ehara S, Oki R, Kanou R (2008) Numerical model of the hydrothermal system beneath Unzen Volcano, Japan. J Volcanol Geotherm Res 175(1-2):35-44. https://doi.org/10.1016/j.jvolgeores.2008.03.032

Gamble TD, Clarke J, Goubau WM (1979) Magnetotellurics with a remote magnetic reference. Geophysics 44(1):53-68

Hata M, Takakura S, Matsushima N, Hashimoto T, Utsugi M (2016) Crustal magma pathway beneath Aso caldera inferred from three-dimensional electrical resistivity structure. Geophys Res Lett 43:10720-10727. https:// doi.org/10.1002/2016gl070315

Hill GJ, Bibby HM, Ogawa Y, Wallin EL, Bennie SL, Caldwell TG, Keys H, Bertrand EA, Heise W (2015) Structure of the Tongariro volcanic system: insights from magnetotelluric imaging. Earth Planet Sci Lett 432:115-125. https:// doi.org/10.1016/j.epsl.2015.10.003

Hoshizumi H, Uto K, Watanabe K (1999) Geology and eruptive history of Unzen volcano, Shimabara Peninsula, Kyushu, SW Japan. J Volcanol Geotherm Res 89(1-4):81-94. https://doi.org/10.1016/s0377-0273(98)00125-5

Hoshizumi H, Uto K, Matsumoto A (2003) Geology and petrology of unzen volcano, field guidebook, A3: unzen and aso volcanoes. XXIII general assembly of the international union on geodesy and geophysics, $\mathrm{p} 11$

Hubert J, Juanatey MDG, Malehmir A, Tryggvason A, Pedersen LB (2013) The upper crustal 3-D resistivity structure of the Kristineberg area, Skellefte district, northern Sweden revealed by magnetotelluric data. Geophys J Int 192(2):500-513. https://doi.org/10.1093/gji/ggs044

Hyndman RD, Shearer PM (1989) Water in the lower continental crust: modeling magnetotelluric and seismic reflection results. Geophys J Int 98(2):343-365. https://doi.org/10.1111/j.1365-246X.1989.tb03357.x

Ichihara $\mathrm{H}$ et al (2011) A fault-zone conductor beneath a compressional inversion zone, northeastern Honshu, Japan. Geophys Res Lett. https://doi. org/10.1029/2011 gl047382

Ikeda R, Kajiwara T, Omura K, Hickman S (2008) Physical rock properties in and around a conduit zone by well-logging in the Unzen Scientific Drilling Project, Japan. JVolcanol Geotherm Res 175(1-2):13-19. https://doi. org/10.1016/j.jvolgeores.2008.03.036

Inoue N (2013) Subsurface structure beneath the Unzen Volcano, Shimabara Peninsula, Kyushu, Japan, based on 2D joint inversion of gravity and magnetic data. In: Proceedings of the 11th SEGJ international symposium

Jones AG (1987) MT and reflection - an essential combination. Geophys J Roy Astron Soc 89(1):7-17. https://doi.org/10.1111/j.1365-246X.1987.tb043 80.x

Kagiyama T, Utada H, Yamamoto T (1999) Magma ascent beneath Unzen Volcano, SW Japan, deduced from the electrical resistivity structure. J Volcanol Geotherm Res 89(1-4):35-42

Karas M, Tank SB, Ozaydin S (2017) Electrical conductivity of a locked fault: investigation of the Ganos segment of the North Anatolian Fault using three-dimensional magnetotellurics. Earth Planets Space 69:107. https:// doi.org/10.1186/s40623-017-0695-2

Käufl JS, Grayver AV, Kuvshinov AV (2018) Topographic distortions of magnetotelluric transfer functions: a high-resolution 3-D modelling study using real elevation data. Geophys J Int 215:1943-1961. https://doi. org/10.1093/gji/ggy375

Kaya T, Kasaya T, Tank SB, Ogawa Y, Tuncer MK, Oshiman N, Honkura Y, Matsushima M (2013) Electrical characterization of the North Anatolian fault zone underneath the Marmara Sea, Turkey by ocean bottom magnetotellurics. Geophys J Int 193(2):664-677. https://doi.org/10.1093/gji/ggt025

Kohno Y, Matsushima T, Shimizu H (2008) Pressure sources beneath Unzen Volcano inferred from leveling and GPS data. J Volcanol Geotherm Res 175(1-2):100-109. https://doi.org/10.1016/j.jvolgeores.2008.03.022

Komori S, Kagiyama T, Utsugi M, Inoue H, Azuhata I (2013) Two-dimensional resistivity structure of Unzen Volcano revealed by AMT and MT surveys. Earth Planets Space 65(7):759-766. https://doi.org/10.5047/ eps.2012.10.005

Komori S, Kagiyama T, Fairley JP (2014) Possibility of effective magma degassing into groundwater flow systems beneath Unzen volcanic area, SW Japan, inferred from the evaluation of volcanic gas fluxes using electrical conductivity structures. J Volcanol Geotherm Res 283:73-81. https://doi. org/10.1016/j.jvolgeores.2014.05.024
Matsumoto S, Shimizu H, Onishi M, Uehira K (2012) Seismic reflection survey of the crustal structure beneath Unzen volcano, Kyushu, Japan. Earth Planets Space 64(5):405-414. https://doi.org/10.5047/eps.2011.11.006

Matsuoka A, Tsutsumi H, Takemura K, Hoshizumi H, Matsumoto A (2005) Slip rates and late Quaternary activity of the Unzen active faults in western Kyushu. Act Fault Res 25:135-146. https://doi.org/10.11462/afr19 85.2005.25_135

Munoz G, Ritter O (2013) Pseudo-remote reference processing of magnetotelluric data: a fast and efficient data acquisition scheme for local arrays. Geophys Prospect 61:300-316. https://doi.org/10.1111/1365-2478.12012

Nakada S, Motomura Y (1999) Petrology of the 1991-1995 eruption at Unzen: effusion pulsation and groundmass crystallization. J Volcanol Geotherm Res 89(1-4):173-196. https://doi.org/10.1016/50377-0273(98)00131-0

Nakada S, Shimizu H, Ohta K (1999) Overview of the 1990-1995 eruption at Unzen Volcano. J Volcanol Geotherm Res 89(1-4):1-22

Nakada S, Uto K, Sakuma S, Eichelberger JC, Shimizu H (2005) Scientific results of conduit drilling in the Unzen Scientific Drilling Project (USDP). Sci Drill 1(5):18-22. https://doi.org/10.2204/iodp.sd.1.03.2005

Nishi K, Ono H, Mori H (1999) Global positioning system measurements of ground deformation caused by magma intrusion and lava discharge: the 1990-1995 eruption at Unzendake volcano, Kyushu, Japan. J Volcanol Geotherm Res 89(1-4):23-34. https://doi.org/10.1016/s0377 $-0273(98) 00119-x$

Nurhasan, Ogawa Y, Ujihara N, Tank SB, Honkura Y, Onizawa S, Mori T, Makino M (2006) Two electrical conductors beneath Kusatsu-Shirane volcano, Japan, imaged by audiomagnetotellurics, and their implications for the hydrothermal system. Earth Planets Space 58(8):1053-1059. https://doi. org/10.1186/BF03352610

Ogawa Y, Uchida T (1996) A two-dimensional magnetotelluric inversion assuming Gaussian static shift. Geophys J Int 126(1):69-76. https://doi. org/10.1111/j.1365-246X.1996.tb05267.x

Ohsawa S, Kazahaya K, Yasuhara M, Kono T, Kitaoka K, Yusa Y, Yamaguchi K (2002) Escape of volcanic gas into shallow groundwater systems at Unzen Volcano (Japan): evidence from chemical and stable carbon isotope compositions of dissolved inorganic carbon. Limnology 3:169-173. https://doi.org/10.1007/s102010200

Okubo A, Nakatsuka T, Tanaka Y, Kagiyama T, Utsugi M (2006) Aeromagnetic constraints on the subsurface structure of the Unzen Graben, Kyushu, Japan. Earth Planets Space 58(1):23-31. https://doi.org/10.1186/BF033 51909

Patro PK, Egbert GD (2011) Application of 3D inversion to magnetotelluric profile data from the Deccan Volcanic Province of Western India. Phys Earth Planet Inter 187(1-2):33-46. https://doi.org/10.1016/j.pepi.2011.04.005

Rung-Arunwan T, Siripunvaraporn W, Utada H (2016) On the Berdichevsky average. Phys Earth Planet Inter 253:1-4

Sakuma S, Kajiwara T, Nakada S, Uto K, Shimizu H (2008) Drilling and logging results of USDP-4 - penetration into the volcanic conduit of Unzen Volcano, Japan. JVolcanol Geotherm Res 175(1-2):1-12. https://doi. org/10.1016/j.jvolgeores.2008.03.039

Seki K et al (2016) Resistivity structure and geochemistry of the Jigokudani Valley hydrothermal system, Mt. Tateyama, Japan. J Volcanol Geotherm Res 325:15-26. https://doi.org/10.1016/j.jvolgeores.2016.06.010

Shimano Y (1999) Hydro-chemical study of spring waters at eastern foot of the Unzen volcano, Shimabara peninsula, western Kyushu (in Japanese). Bunsei Bulletin 11:3-39

Siripunvaraporn W, Egbert G (2009) WSINV3DMT: vertical magnetic field transfer function inversion and parallel implementation. Phys Earth Planet Inter 173(3-4):317-329. https://doi.org/10.1016/j.pepi.2009.01.013

Siripunvaraporn W, Egbert G, Uyeshima M (2005a) Interpretation of twodimensional magnetotelluric profile data with three-dimensional inversion: synthetic examples. Geophys J Int 160(3):804-814. https://doi. org/10.1111/j.1365-246X.2005.02527.X

Siripunvaraporn W, Egbert G, Lenbury Y, Uyeshima M (2005b) Three-dimensional magnetotelluric inversion: data-space method. Phys Earth Planet Inter 150(1-3):3-14. https://doi.org/10.1016/j.pepi.2004.08.023

Srigutomo W, Kagiyama T, Kanda W, Munekane H, Hashimoto T, Tanaka Y, Utada H, Utsugi M (2008) Resistivity structure of Unzen Volcano derived from time domain electromagnetic (TDEM) survey. J Volcanol Geotherm Res 175(1-2):231-240. https://doi.org/10.1016/j.jvolgeores.2008.03.033

Tsukamoto K, Aizawa K, Chiba K, Kanda W, Uyeshima M, Koyama T, Utsugi M, Seki K, Kishita T (2018) Three-dimensional resistivity structure of 
Iwo-yama volcano, Kirishima Volcanic Complex, Japan: relationship to shallow seismicity, surface uplift, and a small phreatic. Geophys Res Lett. https://doi.org/10.1029/2018gl080202

Tsutsumi H (1987) Active faults in Unzen Volcanic Region, Central Kyushu. Act Fault Res 4:55-64

Tsutsumi H. (2015) 1:25,000 active fault map in Unzen faults and its vicinity. Technical report of the Geospatial Information Authority of Japan (D1-No. 739), $13 p$

Umakoshi K, Shimizu H, Matsuwo N (2001) Volcano-tectonic seismicity at Unzen Volcano, Japan 1985-1999. J Volcanol Geotherm Res 112(14):117-131. https://doi.org/10.1016/s0377-0273(01)00238-4

Unsworth M, Bedrosian PA (2004) Electrical resistivity structure at the SAFOD site from magnetotelluric exploration. Geophys Res Lett. https://doi. org/10.1029/2003gl019405

Unsworth MJ, Malin PE, Egbert GD, Booker JR (1997) Internal structure of the San Andreas fault at Parkfield. Calif Geol 25(4):359-362. https://doi. org/10.1130/0091-7613(1997)025\%3C0359:ISOTSA\%3E2.3.CO;2
Usui Y (2015) 3-D inversion of magnetotelluric data using unstructured tetrahedral elements: applicability to data affected by topography. Geophys J Int 202(2):828-849. https://doi.org/10.1093/gji/ggv186

Xiao QB, Yu G, Jing LZ, Oskin ME, Shao GH (2017) Structure and geometry of the Aksay restraining double bend along the Altyn Tagh Fault, northern Tibet, imaged using magnetotelluric method. Geophys Res Lett 44(9):4090-4097. https://doi.org/10.1002/2017gl072581

Yamaguchi S, Ogawa Y, Fuji-ta K, Ujihara N, Inokuchi H, Oshiman N (2010) Audio-frequency magnetotelluric imaging of the Hijima fault, Yamasaki fault system, southwest Japan. Earth Planets Space 62(4):401-411. https ://doi.org/10.5047/eps.2009.12.007

Yan P, Andersson M, Kalscheuer T, Juanatey MAG, Malehmir A, Shan CL, Pedersen LB, Almqvist BSG (2016) 3D magnetotelluric modelling of the Alno alkaline and carbonatite ring complex, central Sweden. Tectonophys 679:218-234. https://doi.org/10.1016/j.tecto.2016.05.002

\section{Submit your manuscript to a SpringerOpen ${ }^{\circ}$ journal and benefit from:}

- Convenient online submission

- Rigorous peer review

- Open access: articles freely available online

- High visibility within the field

- Retaining the copyright to your article

Submit your next manuscript at $\boldsymbol{\nabla}$ springeropen.com 